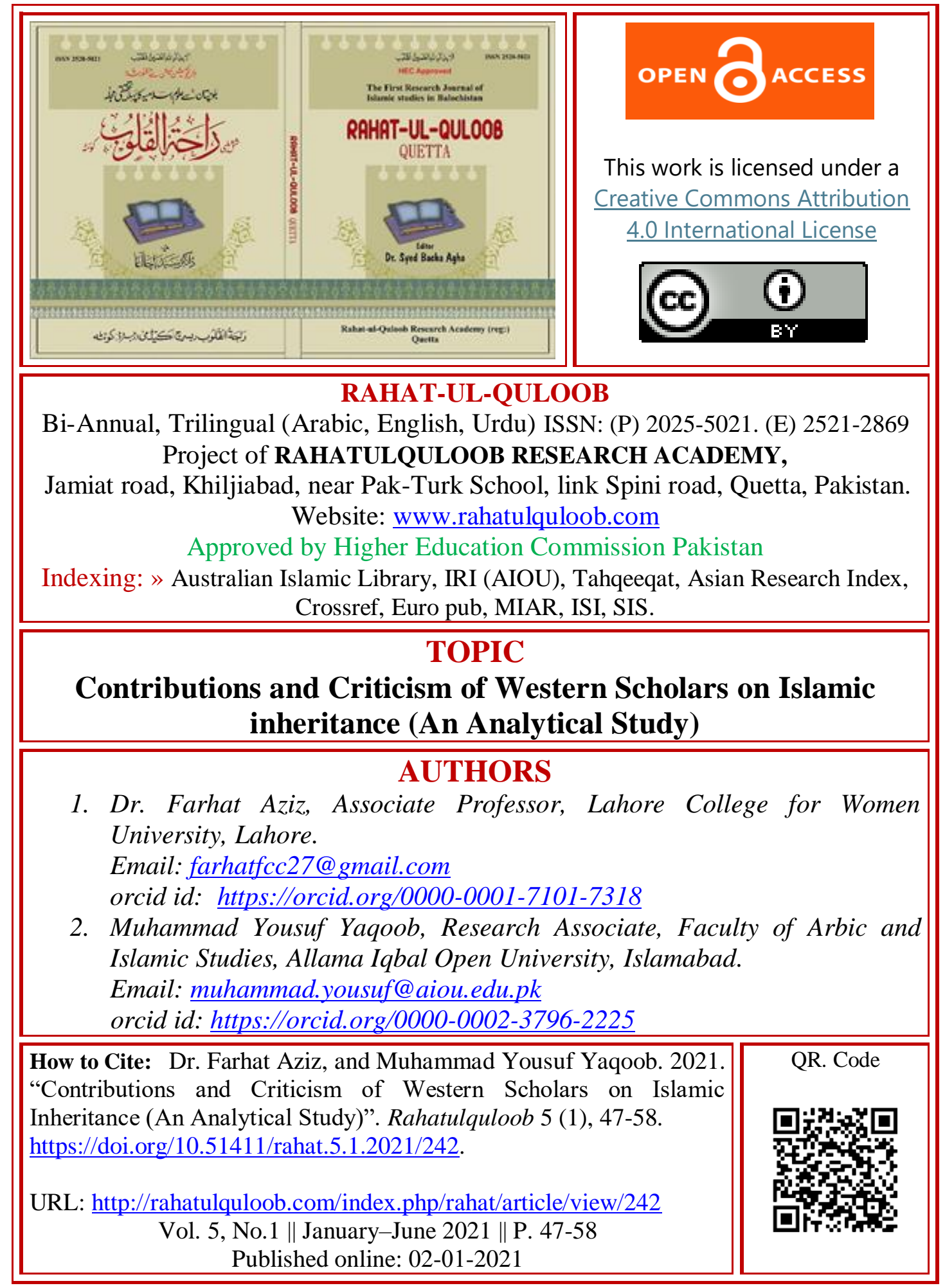




\title{
Contributions and Criticism of Western Scholars on Islamic inheritance (An Analytical Study)
}

\section{ABSTRACT:}

\author{
${ }^{1}$ Dr. Farhat Aziz, ${ }^{2}$ Muhammad Yousuf Yaqoob
}

In this paper, the criticisms and contributions of Western Scholars and their impacts on society have been discussed. To study the civilization's heritage, history, language, literature, fine arts, sciences, and sociology, of the people of East, by the westerns, is called Orientalism. In the ancient Arabic dictionary, the term "orientalism" is not present. In Europe, after the Renaissance, to introduce the East in the West, and to point out the expected interests of the West in the East, the Western Scholars performed their duty elegantly. All of the ancient and modern western scholars wrote about the Holy Qur'an, and almost all of them neglected its present order and tried to determine the order of revelation of Qur'anic verses according to their own mind. Torrey of Yale spent his whole life to find out contradictions in the book of God. Bell of Edinburgh applied the rules of higher criticism on Qur'anic injunctions. Many other orientalists as Arthur Jeffery, A.T.Welch, J.D.Pearson, Montgomery Watt and Karen Armstrong are also written about the Qur'an and biography of the prophet (PBUH). Western scholars also have a great role in denouncing the history of Islam. It is the need of the era to go through their literary efforts to explore their objectives and outcomes. It is also essential to study their struggle to prove about their right and wrong points. At a time, the Orientalists gained popularity among all schools of thought of different religions. This study is necessary and beneficial for all students, teachers and research scholars of every field of life.

Keywords: Western Studies, Contributions, Criticisms, Movements, Objectives Literature Review:

As far as the review of previous work on this subject is concerned, there is enough information about the English sources on Orientalism. i.e. Orientalism is a 1978 book by Edward W. Said. Widely regarded as Sadegh Hedayat's masterpiece, the Blind Owl is the most important work of literature to come out of Iran in the past century.' "Season of Migration to the North" is an Arabian Nights in reverse, enclosing a pithy moral about international misconceptions and delusions. Leg over Leg recounts the life, from birth to middle age, of 'the Fariyaq,' alter ego of Ahmad Faris al-Shidyaq, a pivotal figure in the intellectual and literary history of the modern Arab world. Drifting Cities: A Trilogy (Modern Greek Writers Series) Paperback-July 1, 1996.The tales told by Scheherazade over a thousand and one nights to delay her execution by the vengeful King Shahryar have become among the most popular in both Eastern and Western literature. From the epic adventures of 'Aladdin and the Enchanted Lamp' to the farcical 'Young Woman and her Five Lovers' and the social criticism of 'The Tale of the Hunchback', the stories depict a fabulous world of all-powerful sorcerers, jinns imprisoned in bottles and enchanting princesses. But despite their imaginative 
extravagance, the Tales are also anchored to everyday life by their bawdiness and realism, providing a full and intimate record of medieval Eastern world. Dr. M. A. Chaudhary is the pioneer of orientalism studies in Pakistan. He has written so many articles to illuminate the orientalist objectives and goals and I have consulted mainly his research on "Orientalism" and Orientalism on Variant readings of the Qur'an (The case of Arthur Jeffery) to write this article in English. Although number of books in Urdu have also been written on orientalism. i.e. Islam and Mustashriqeen by Dr.Hafiz Muhammad Sarwar, Islam and Mustashriqeen by Saeed Sabah ud Din Abdu r Rehman, Islam, Paighambar Islam and Mustashriqeen, Qur'an.e.Kareem and Mustashriqeen by Abdul Fatah, Mustashriqeen and English Translations of the Holy Qur'an et. However, in this research specifically the Contributions and Criticism of Western Scholars on Islamic inheritance have been examined. A well-known research methodology on a scholarly level based on the content comparison method is adapted in this article. It has been tried to get material about this topic from authentic books to analyze and investigate.

\section{Introduction:}

The Holy Qur'an is the most protected book revealed by Allah. But a number of western scholars are resolutely trying to prove this reverend book as falsified like other revealed books. There has been a great difference of opinion between eastern Muslim theologians and the western scholars on the preservation of this book of Allah, and the western scholars have missed no chance of opposing strongly in this regard. To study the civilization's heritage, history, language, literature, fine arts, sciences, and sociology, of the people of East, by the westerns, is called Istishrāq (Orientalism). In the ancient Arabic dictionary, the term "Mustashriq" is not present. In the same way, a person who wrote against Islam, due to differences between religions of the world, or while discussing different creeds, has not been called a Mustashriq, in ancient accounts. However, we can give the term Mustashriq to the nature of the work of present western researchers and western biographers, or in ancient period, to the Jews and Christians of the early period of Islam, who piled up a large number of objections against Islam. The movement of Orientalism was started after Crusades (eleventh to the thirteenth century) as a religious movement, and the person who, for the first time, started a movement against Islam was John of Damascus of the seventh century. The era of Crusades was the age in which Christian theologians and researchers tried to refute Islamic beliefs, to eclipse the perfect example of the Holy Prophet (PBUH), and to prove the Qur'an as His (PBUH) as creation. Thus, in Europe, after the Renaissance, to introduce the East in the West, and to point out the expected interests of the West in the East, the Western Scholars performed their duty elegantly. Though the western scholars discussed manuscripts related to Islamic heritage along with all aspects of Islamic sciences, including tafsīr, Hadith, Fiqh, Seerah, history of Islam, tasawuf, Arabic grammar, language, and literature, they particularly took up the Holy Qur'an and the personality of the Holy 
Prophet (PBUH), for discussion. All of the ancient and modern western scholars wrote about the Holy Qur'an, and almost all of them neglected its present order and tried to determine the order of revelation of Qur'anic verses according to their own mind. Torrey of Yale spent his whole life to find out contradictions in the book of God. Bell of Edinburgh applied the rules of higher criticism on Qur'anic injunctions. Western scholars also have a great role in denouncing the history of Islam, Qur'an, Hadith, Seerah, Fiqh, and Arabic Literature, etc. It is the need of the era to go through their literary efforts to explore their objectives and outcomes. It is also essential to study their struggle to prove their points wrong. At a time, the Orientalists gained popularity among all schools of thought of different religions. In this paper, the history of Western Studies and its impacts on society has been discussed. This study is the need of the time and beneficial for all students, teachers and research scholars of every field of life.

${ }^{1}$ Orientalism or Istishrāq has been derived for Western Studies from Arabic origin 'Sharq', but it is not ancient, and Arabic grammar does not possess the verb or noun for 'Sharq', or Orientalism / Western Studies. In English, Orientalism is used for the expertise and command in arts and crafts of the East. In the same way, a western scholar is a person who willingly becomes an expert in Eastern art and craft. Another definition of Orientalism is 'knowledge of east, eastern culture, or an expert in eastern civilization. One more definition of Orientalism is Western Studies as Eastern knowledge and studies and Islamic and Arabic writings in his dictionary and has defined orientalist as the expert of Eastern studies and Islamic knowledge. ${ }^{2}$ In this way, we can say that Orientalism is the study of cultural heritage, history, languages and crafts and knowledge and civilization of the cost. ${ }^{3}$ The word Western Scholar can be taken in vast meanings as the scholar of Islam and Islamic civilization, Experts of Islamic \& Arabic languages. ${ }^{4}$ Dr. Umar Farrukh has protested that Najib Aqiqi included all Muslim scholars and expertise among Western Scholars rather only a European or American non-Muslim can be the orientalist. ${ }^{5}$ There is no evidence for the question of how and when the Orientalism, movement started and who was the founder of this movement whether they were Muslim or Non-Muslim. Arabic grammar has no world Orientalism and in the same way, no one had been given none of the Orientalists who wrote against Islam in the ancient discussion of various religions of the world. ${ }^{6}$ Nowadays, we can call a Jew or a Christian Western Scholars according to their writing and creations. The movement of Orientalism started properly and completely under the observation of the Roman Empire and pop after the crusades (11 to 13 A.D.) as a religious movement. When Arabic, Hebrew, and Persian languages were taught to the preachers of Christianity in their educational institutions in order to train these preachers. ${ }^{7}$

The Orientalism started in the colonial era of the western invaders nowadays. The orientalist main topic has been Islamic heritage, Tafsīr, Hadith, Fiqh, Sirah, History of Islam, Tasavuf, Arabic grammar, language, literature, and philosophy but they especially 
targeted the personality of the Holy Prophet (PBUH). Western Scholars seemed to guide the western invaders politically and scholarly. ${ }^{8}$ According to Abu Al-Hassan Al Nadvi, the orientalist played a role sanitary an inspector who investigated filth and dirt, in the same way, the Western Scholars were bent upon finding filthy and immoral fake aspects of Islam to defense the Muslim and they misguided the readers to a great extent. ${ }^{9}$ Qur'an has been the favorite topic of the ancient and modern Western Scholars as they always pinpoint the arrangements of the Surah in Qur'an as they discussed the Nazooli Tarteeb, of Qur'an so that they could prove that the Holy Prophet (PBUH) created Surah to fulfill the needs of the situation and it was not a divine book. Many Western scholars have tried to prove Qur'an as a supplement of Bible and Jewish origin as Arthur Jeffery appreciated Bell of Edinburgh and Torrey of Yale for their research that the Holy Prophet (PBUH) again and again, write the Qur'anic Surah so that it could be the part of a book. ${ }^{10}$ Arthur Jeffery's comment exposed the behavior of the Orientalist that Christianity could survive without the New Testament but Islam could not be alive without Qur'an. ${ }^{11}$ The central position of the Qur'an compelled the Western Scholars to write their lives in finding paradoxes in Qur'an, human efforts in Qur'an compelling and evolution in Surah of Madni and Macci. ${ }^{12}$ After Qur'an, the personality of the Holy Prophet (PBUH) has been the favorite target of the Western Scholars as they always associated all moral, physical and mental discover with him (PBUH). Like ancient orientalist the scholars of area study try to prove the same things about him (PBUH), e.g., the famous Jewish orientalist writes in Keppel Gilles' book: "Muhammad and Firaun" that "Muhammad's life has been divided among two parts i.e. the Prophet (PBUH) was a rebel in the state of Macca and the ruler of Madina in the second part and all his (PBUH) struggle to continue until the Govt. ${ }^{13}$. Bernard Lewis, FBA (31 May 1916-19 May 2018) tries to prove that all Muslims follow the Sunnah of Hazrat Muhammad and he tries to endanger the lives of the Muslims in Europe, Canada and America by saying that the Muslim is whether rebel or ruler. The double standard of the west in the research of Islamic origin gave birth to a strong reaction. In 1982, a seminar was held by Dar-ul-Musanifeen Azam Garh under the topic "The Orientalist and Islam" and all the articles read in between 1985 and 1986. MajlaulNawal Saudi Arabia published a magazine never Al-Istishraq wall Mastasriqoon in 1989. Maktab Al-Tarbiya Al-Arabi Ladool Al-Khaleej published a very complicated book Manhaj Al-Mustishriqeen from Riyadh Saudi Arabia in 1985, in which detailed analysis was presented of views of the orientalist about the Seerah Islamic dogmas, Law and Sharia Philosophy Islamic history and Arabic language and literature. A Christian doctor Edward Wadie Said (1 November 1935 - 24 September 2003) has done the most important deed he has proved the orientalist the tool for imperialism which compelled them to call an expert of the study area. It is an eye open fact that the Western Scholars brought many precious, ancient and lost books of Islamic heritage to light. We should give the devil his due as we must acknowledge that numerous Western Scholars devoted their lives to study and research Islamic heritage 
and arts and literature as Maulana Abu-ul-Kalam Azad said: without this precious research and books, Islamic literature and Muslim heritage would be empty. ${ }^{14}$ In the same, 'Allāmah Šiblī No'mānī; (3 June 1857-18 November 1914) appreciated Western Scholars on publishing such precious books like Tabqat Ibn e Saad, Manaqib Umar Ibn Abdul Aziz, Tijara-ul-Uman, etc which saved history, geography, grammar, medicine, philosophy and literature of the Muslim from destruction ${ }^{15}$ In the 19th century, Flascher published Tafsir al-Baydawi and Al Mafsal of Zamakhshari and his pupil Zakho published Ma al hind and Al Asar Al Baqiya of Abū Rayḥān Muhammad ibn Aḥmad Al-Bīrūnī (973-1050), Flugel published Kashf al-zunun : Haji Khalfah, d. 1658.

Westnflit published wafat ul Ayyan Ali Ibn Khakan, Tahzeeb-ul-Asma le Navvi, Tazkiratul Huffaz Imam Az-Zahabi, Ibn Qutayba Kitab al-mâ'arif, Al Sir'ah Le Ibine Hasham, and Mu'jam al-Buldan Al Yaqoot Al Hamawi, after great research Hartoic publishes Al kitab Le Saibwia and Tarikh Al Fakhri in the 20th century. D. Khwiya published Fatuh Ul Baldan Le Blazri and Tarikh Al-Rusal wa Al-Malook LeTabri, Margolaith published Muajam Al Udbda Le Yaqoot Al Hamvi and Kitab Al Ansab Le Samani and translated Surah Al-e- Imran and Rasale Abi-A'la-Al Umari. Kranko . published Tafsir Baizavi, Jamhara Al-Lughat Le Ibin duriad and Al-Durr ul Kamina Le Ibn e Hajar and Proftasal published Ansaab ul-Arab Le bin Hazam. Sir Charles Loyal published Al mufzalyat ma Sharah Al Anbari with English translation. William writgt brought al Kamil Le Mubard to light. Renald Nicolson, Montgomeri watt, Hamlton Gub, A. J. Arbari, Sir William Muir, Thomas Arnold, Carl Brokalman and Wensinck are deserved much prize and appreciation for their research and writings. Al Muajam ul Mufahris le Lafaz Al-Hadih ul-Nabvi is much praiseworthy.

It is true that the Western Scholars of the present age performed very difficult and compact deeds in Islamic studies and revival of Islamic heritage. The initial stage of Orientalism started with the advent of Islam when suddenly Islam captured the panorama of the whole world forcefully and all the Christian, Persian and other Empires surrendered before Islam. In the beginning, the pagans of Mecca offered a diplomatic suggestion that one year, all of them including Muslim would worship idols and another year all the people including pagans worship Allah ${ }^{16}$ they were refused and rejected and sternly told that ${ }^{17}$ 'Nor will you be worshippers of what I worship' 18 Allah asked Hazrat Muhammad (PBUH) 'They wish that you would soften [in your position], so they would soften [toward you]. ${ }^{19}$ In Madina, the Christians and the Jews wanted the same things. Indeed, those who disbelieve in Allah and His messengers and wish to discriminate between Allah and His messengers and say, "We believe in some and disbelieve in others," and wish to adopt a way in between ${ }^{20}$ Allah says:' And never will the Jews or the Christians approve of you until you follow their religion. Say, "Indeed, the guidance of Allah is the [only] guidance." If you were to follow their desires after what has come to you of knowledge, you would have against Allah no protector or helper. ${ }^{21}$ Allah says:' O 
you who have believed, do not take the Jews and the Christians as allies. They are [in fact] allies of one another. And whoever is an ally to them among you then indeed, he is [one] of them. Indeed, Allah guides not the wrongdoing people. ${ }^{22}$

With the advent of Islam, Jews and Christians were bent upon intruding in Islamic society and Muslim and Publicized fake things against the Holy Qur'an and Hazrat Muhammad (PBUH) John of Damascus was the first orientalist, which created a fake and abusive discussion about Hazrat Muhammad (PBUH) so that he (PBUH) appeared as a legendary character. John's abusive creations became the origin for the upcoming Western Scholars. According to Prof. Syed Habibul Haq Nadvi, John was the first who raised vulgar objections against the divine personality of Hazrat Muhammad (PBUH), which became interesting topics for the Western Scholars of the future. He created novelty in the matter of Zainab binte Hijrah and Zaid bin Harris and he also provoked the number of wives and other matters to an extent. ${ }^{23}$ After John of Damascus, other Christian and Jewish Scholars discussed the Qur'an and personality of Hazrat Muhammad (PBUH) for many hundred years and such unbelievable and fake stories were created in which Hazrat Muhammad (PBUH) had been presented a well-educated person and he (PBUH) created Qur'an after collecting Bible and Taur'ah contexts. He (PBUH) was also a magician rather he (PBUH) was a cruel, stern terrorist and sexually vulgar person. ${ }^{24}$ A French Orientalist Carra de Vaux) says: Hazrat Muhammad (PBUH) has been a defame and worst person among the west and every vulgarity and moral ambiguity was also associated with him. ${ }^{25}$

During 11th century A.D, many hateful and ignorant information about Islam and the Muslim prevailed among the west e.g. The Roland's going was very popular among the Christians which was composed during crusades in which the Muslim were declared idol worshipers as it had been said that the Muslim were brave warriors but also, they worshiped the idol of Hazrat Muhammad (PBUH) along with other deities. ${ }^{26}$ During the earlier 12th century A.D. only two orientalists are prominent who are very wisely and objectively analyzed the life of Holy Prophet (PBUH) and Islamic teaching without any prejudice and romanticism. Among them, peter Alfonsi who was a Spanish Jew who embraced Christianity in the first decade of eleven century and he was the doctor of British King Henry I and the latter one is William of Malmesbury who clearly declared that the Muslims did not worship Hazrat Muhammad (PBUH) rather they believed in Oneness of God ${ }^{27}$ Crusades continued from 11th to 13th century A.D and during this upon supervising the Christian scholars and researchers to defame and misguide about the Holy Prophet (PBUH) and Islamic teachings. A well organized and perfect Western Scholars movement started through establishing special departments for Islamic preaching in Roman and other European universities. Pope Clement 1305 A.D, declared a dishonor for the Christian areas to have Muslim inhabitants. In the same era, French king Charles of Anjou attacked Cissli and Italy and excluded the native Muslims from there. Dante was an orientalist poet who stood as a milestone $\mathrm{b} / \mathrm{w}$ dark ages of Europe and Renaissance, wrote the Divine comedy 
after great meditation about Islam, anyhow, his behavior towards the Holy Prophet (PBUH) rude and stern. ${ }^{28}$ He felt sympathy for Ibn-e-Sina and Ibn-e-Rushd. His book changed the mentality and behavior of Christian Scholars. ${ }^{29}$ During the 17th century, the universities of Paris, London, Oxford, Cambridge, Glasgow, Edinburgh and Saint Andreas started special departments for teachings of Eastern subjects. There were three thought of scholars of Western Studies, i.e.

The traditional the material of dark ages;

Islamic and Arabic origin which was high jacked;

The biographies of different orientalist who visited and various Muslim countries 30

The first French translation of the Qur'an was done by Andre du Ryer, which was cheap and sub-standard. On the basis of this translation, Alexander Ross translated Qur'an in 1649 in which he followed his predecessors as he wrote in the preface. The great Arabic fraud, at loss reached France, his Qur'an is full of mistakes and the creation of Muhammad's shrewd brain. He (PBUH) had a trained pigeon, that whispered in his ear. Which he (PBUH) declared in revelation. ${ }^{31}$ The Christian could not understand sympathetically Muslim and Bed Well, wrote his book "Muhammad. The imposture in which he disregards Hazrat Muhammad (PBUH), Najib Al-Aqiqi declared Bed Well a stern prejudice Western Scholars. ${ }^{32}$ Even Martin Luther called Hazrat Muhammad (PBUH) Yajooj Majooj and could not do justice with Islam and the Holy Prophet $(\mathrm{PBUH})^{33}$ the present and third period of Orientalism started in the 18th century, which continued till day. During this era, the western world became aware of the new horizon of life through knowledge and weak countries surrendered before the west one by one. The west learned abruptly local languages and studied the occupied area's civilization and folk. The west did great efforts to preserve the knowledge heritage, the revival of a grammatical arrangement of local languages and history. The west wanted to get complete information about the colonial nations and they revived the tradition of Orientalism as the Western Scholars also performed the duties of advisors for the Govt. That's why the majority of orientalist was soldiers who willingly learned local languages and started to write. During the 19th century, the orientalist published such books again which had been hidden in the dust of time, e.g., Sirah Ibn-e-Hisham, Al-Maghazi al Waqidi, Tabqat Ibn E Saad, and Seerah-e-Rasool of Ibne Jureir AlTabari etc., which provoked others to create new books. According to Edward Said, Britain and France played vital royal in establishing well managed and modern orientalism Silvester De Sasi ${ }^{34}$ of France and Edward William Lane ${ }^{35}$ Can be the founder of modern orientalism Sasi also wrote about the Sasani's Iran whereas Edward William lane translated Alf-Lailla, some precious books, articles, eight volumes of Mad al-Qamoos in English which his grandson Lane completed it and published from London, \& which is included among basis of Arabic grammar till today. Both of them had been the main source for the upcoming people even there was a majority of Sasi's pupils in the court of Napoleon ${ }^{36}$ After the Renaissance in Europe, the orientalist performed the task of introducing east and eastern civilization in the west. The 
imperialistic and colonial European Countries aimed at continuing their rule and Govt. on the permanent and strong basis after closely and deeply analyzing the languages, literature, cultural, religions, habits, and custom, and traditions of the occupied areas, e.g., in France, in the last decade of 18th century, it had been arranged to teach Arabic Persian and Turkey for the teaching of al-Sunnah Sharqiya .

The topic of this course was Egypt and various experts or orientalists of historian, linguists, chemists, archaeologists Surgeons, biologists and other studies, who deeply studied the topic and created their findings which were published in the first decade of eighteen century in twenty-three volumes. ${ }^{37} \mathrm{~A}$ division of the French Army was engaged in this mission about Egypt and in the same way, some surveys were done in Al-Jazira and Morocco. ${ }^{38}$ Western Scholars reports compelled the occupying forces to decide the fate of these areas. Abdul Rahman Momin has greatly and correctly commented the journey of orientalism by saying that the orientalist made the target of their attention the 'base of the religion of Islam' the evident and their research was about various Islamic studies and its Manuscripts, in this way the orientalist became the experts of area study in the middle of the 20th century but their thinking was badly affected by crusades ${ }^{39}$ During the orientalism movement, the European countries expended a lot as it was $35 \%$ of the whole world in eighteen fifteen and it became vast till $85 \%$ in $1914{ }^{40}$ Orientalism has created many subjective disputes in the modern ages Edward Said regards orientalism as the guiding power of colonial and imperialistic powers. Orientalism flourished through the Christian priests who studied Arabic in order to provoke people against Islam and the Muslim and in the same way, the modern countries promote orientalism to use it for colonial aims, political intentions, and religious discrimination. Whereas, Najib Al-Aqiqi declares it as the movement of knowledge which appreciated research, translation, rules, and regulation of literature and Islamic studies. ${ }^{41}$ The writers of orientalism in the Oxford Encyclopedia of the Modern Islamic world declared orientalism movement as a romantic adventure in spite of its educational and meditative elements. ${ }^{42}$ After analyzing the performance of orientalism during three centuries, it is said that it was the tool for the west to control the resources of the nations of the world. ${ }^{43}$ The west directly occupied Islamic countries and Imperialism changed the face of orientalism. ${ }^{44}$ Since 1783 the oriental conferences were held and everybody was allowed to attend but later in 1973-three, it has been held in secret rooms on the suggestion of Jewish orientalists like to call adviser or experts of study area after a second world war. ${ }^{45}$

In the present era, the Orientalism started in the colonial era of the western invaders. The orientalist main topic has been Islamic heritage, Tafsīr, Hadith, Fiqh, Sir'ah, History of Islam, and Tasa'vuf, Arabic grammar, language, literature, and philosophy but they especially targeted the personality of the Holy Prophet (PBUH).

The main objective of this research is to suggest Western Scholars apply a neutral approach to a required standard of Islamic inheritance. It is essential to prove Qur'anic eloquence and oration is of God. It is the tragedy of the orientalist that they consider 
all traditions found in any tradition heritage of the Muslims are authorities and objectionable. In this research, the objections of the orientalist are an illumination to examine the standard of the modern system of criticism and rectifying. Sometimes the apparent meanings of a tradition are different than real meaning, therefore, to find out seal meaning and argument accordingly is the basis of this research. It is essential to have knowledge of traditions to gain benefit from Qur'anic traditions. Therefore the objections of the orientalist should be examined in the background of 'uloom ulHadith to get an accurate conclusion. This point should especially be considered in this research of orientalism. Non acceptance of baseless traditions and their importance to the orientalist are stated. The application of rules of Higher criticism on Qur'anic text by the orientalist and a suggestion for them to be adopted their research authenticity before considering those traditions important in their criticism.

Keeping in view the objectives of research I have selected the topic of orientalism to examine critically the point of view of Western Scholars. The Encyclopedia of Islam has been the main source for the whole of the world to comprehend Islam but the material presented here is misleading in it and other orientalist sources prescribed in this research. It is our natural and communal responsibility to introduce a factual position of orientalist research that is the basic objective of the research.

Allah says in Qur'an: (Had it been from other than Allah they would surely have found there in many discrepancies). ${ }^{46}$

Another verse of Holy Qur'an is:

We have, without doubt, sent down the Message and we will assuredly guard it (from corruption). ${ }^{47}$

A well-known research methodology on the scholarly level based on comparative and analytical method need to be adopted in this research. Need to get material about this topic from authentic books to analyze and investigate. To avoid the polemical approach, the discussion about trust-worthy and untrustworthy Qur'anic traditions needs to be rejected.

\section{CONCLUSION:}

It is true that the Western Scholars are praiseworthy which brought Islamic heritage to light but it created a big flam that the whole Islamic world began to depend upon the western research and the fact is that the western research became authentic in studying sharia of Islam, Islamic dogmas and Encyclopedia of Islam in Holland is its great example. The new generation of Muslim also follows the west. It is the need of time that new research should be done in this regard. The Muslim has become aware of the demands of time and the orientalism has become their target. New findings and research are being done in the fields of Islamic heritage and history. Many centers of research also work in Europe and America. 


\section{RECOMMENDATIONS:}

1. The panorama of the international world demands that the Muslim must promote Occidentalism in front of Orientalism. The Muslim should be aware of the findings of the areas of Orientalists and Islamic inheritance.

2. It is our natural and communal responsibility to introduce a factual position of orientalist through seminars, conferences, research that is the basic objective of the research.

\section{References:}

${ }^{1}$ Islahi, Sharf Ud Din, Mustasriqeen Istishraq and Islam and Mustashriqeen, (Saba hu Din Abdul Rehman, Muarf Az, am Gahrh: Dar-ul-Musnfieen, 1986), P: 48-50. / M. A, Chaudhary, 'Orientalism' (Lahore: 'Takmala', Urdu daira Maarif e Islamia, University of the Punjab, 2002). (Dr.M.A. Chaudhary is the pioneer of orientalism studies in Pakistan. He has written so many articles to illuminate the orientalist objectives and goals and I have consulted mainly his research to write this article in English) ${ }^{2}$ Hans Wehr, Dictionary of Modern Arabic, (New York: Ed. J. M Crown, 1961)

http://www.oxfordbibliographies.com/view/document/obo-9780195390155/obo-97801953901550058.xml

${ }^{3}$ Maan Z Madina, Arabic English Dictionary.(NewYork: 1973),

${ }^{4}$ Al-Shaqheer, Al-Mushtasriqun wa darasatul Qur'ania, ( 1983), P-11

${ }^{5}$ Rampuri, Muhammad Yousaf, Tahrik-e-Ishtisraq, (Deoband, Majala Darul uloom, 1988),P-351-35

${ }^{6}$ Umer Farukh, Al-Istashraq, ( Majala Al Minhal Naqvi, April 1989), P-15

${ }^{7}$ Hussain Nisar, Al-Istishraq Dein ul Mastalih wal Marifhoon

${ }^{8}$ Daqhir, Yousaf Asad, Masadir Al Darasa Al Abdia, (Lebon, 1956) P-772

-Please see for detail, Al Mustashrqeen, (Dar ul Muarif,Cario, 1964), vol: 1, P-43-114

- M. A, Chaudhary, 'Orientalism' ('Takmala', Urdu daira Muarif e Islamia, 2002)

${ }^{9}$ Jeffery, Arthur, The Koran; Selected Suras, (New York: The George Macy Companies LTD) P-14-15

${ }^{10}$ Jeffery, Arthur, The Koran; Selected Suras, P-1

${ }^{11}$ M.A. Chaudhary, 'Orientalism on Variant readings of the Qur'an, (The American Journal of Islamic

Social Sciences, 1995), V -12, No-2, P170 to 181

${ }^{12}$ Kippel Gilles, The Prophet and Pharaoh: Muslim Extremist in Egypt (London: Distributed by Zed Books, 1985), P, 1-11

${ }^{13}$ M. A. Chaudhary, 'Orientalism' ('Takmala', Urdu daira Maarif e Islamia, 2002

${ }^{14}$ Farooq, Istashraq, P-15-17

${ }^{15}$ Kippel Gilles, The Prophet and Pharaoh: Muslim Extremist in Egypt, P, 11-18

${ }^{16}$ Edward Saeed, Orientalism, (New York, Pantheon, 1978) P, 230-36

- https://en.wikipedia.org/wiki/Orientalism_(book)

${ }^{17}$ For Details please See Seer'ah Ibn e Hasham \& amp; Tar'ikh Ibn e Jurieer Al Tabri

- M. A. Chaudhary, 'Orientalism' ('Takmala', Urdu daira Muarif e Islamia, 2002

${ }^{18} \mathrm{Al}$ Quran, 109: 5

${ }^{19} \mathrm{Al}$ Quran, 68:9

${ }^{20} \mathrm{Al}$ Quran, 4:150

${ }^{21} \mathrm{Al}$ Quran, 2:120

${ }^{22} \mathrm{Al}$ Quran, 5: 51

${ }^{23}$ Rampuri, Tahrik-e-Ishtasraq, (ND), P-41-43

${ }^{24}$ Ibid, 42-43

${ }^{25} \mathrm{Al}$ Thami, Naqra, Al Quran wa Al mushtasriqoon Minhat ul Mustashrqeen (Li dul Al Khaleel :

Maktab Al tarbia Al Arabi, 1988), Vol-1, P-22 
Karen Armstrong, Muhammad, -A Biography of the Prophet (New York, 1992), P.25

https://www.researchgate.net/publication/323785309_Karen_Armstrong_as_a_Biographer_of_Muham mad_A_Critical_Study_of_Muhammad_Prophet_for_Our_Time

${ }^{26} \mathrm{https} / / /$ oi.uchicago.edu/sites/oi.uchicago.edu/files/uploads/shared/docs/medieval_islam.pdf

${ }^{27}$ Ibid-29 - (Pope Clement time period was1305 A.D)

${ }^{28}$ Ibid 28 / (Dante time period was1265 to 1321 A.D)

${ }^{29}$ Ibid 29 \& Rampuri, Tahrik-e-Istashraq, P-42-43 -

${ }^{30}$ Ibid-P-44

${ }^{31}$ Jeffery, Arthur, The Koran; Selected Suras (New York, 1958), P-17-18

${ }^{32}$ Najeeb-Aqeeqi, Al MushtashrIqun, P-44 / (Bed Well time period was1632)

${ }^{33}$ Rampur, Tahrik-e-Istashraq, P-44

${ }^{34}$ Silvaster de sasi Edward William Lain Please see for details Al-Aqeeqi, Al Mustashriqoon, P-179182 and 480-487 / (Silvester De Sasi time period was1758-1838)

${ }^{35}$ Edward Saeed, Orientalism, P, 17-18 / (Edward William Lane time period was 1801-1876)

${ }^{36}$ Ibid, 83, 127, 129, 130

${ }^{37}$ Ibid, P, 83-85

${ }^{38}$ Orientalism;' The Oxford Encyclopedia of the Modern Islamic World, P, 267

${ }^{39}$ Momin, Abdul Rehaman, On Islamic Fundamentalism, (Hamdard Islamicus: ND), V, 4, P37-39

${ }^{40}$ Edward Saeed, Orientalism, P, 41

${ }^{41}$ Najeeb Al Aqeeqi, Al Mustashrqeen, P-1148-1166

'Orientalism;' The Oxford Encyclopedia of the Modern Islamic World, P, 267

42 https://www.khanacademy.org/humanities/becoming-modern/intro-becoming-modern/a/orientalism

${ }^{43}$ Al-Samrai, Noman, Abdul Raziq, Al-Fikar Al Arabi wa Al Fikar Istashraqi, (Al Riaz: 1989 ),P-24-30

${ }^{44}$ Ibid 36

${ }^{45}$ AL-Nadui, Abdul Hassan, Al-Islamat Bain Kitabiat Al Mustashrqeen wal Bahiseen Al Muslimeen, (Musisa Al Risalah, 1986), P-15-16 / M.A,Chaudhary, 'Orientalism' ('Takmala', Urdu daira Muarif e Islamia, 2002). Please see for details:

https://sites.evergreen.edu/politicalshakespeares/wp-content/uploads/sites/33/2014/12/Said_full.pdf https://monoskop.org/images/4/4e/Said_Edward_Orientalism_1979.pdf

http://arabstereotypes.org/why-stereotypes/what-orientalism

http://www.tobiashubinette.se/orientalism.pdf

http://www.oxfordbibliographies.com/view/document/obo-9780199874002/obo-9780199874002-

0010.xml

${ }^{46}$ Al-Qur'an, 4:82

${ }^{47}$ Al-Qur'an, 15:9 